\title{
Factors Influencing the Extent of Push-Pull Technology Expansion Among Smallholder Maize Farmers in Homa Bay, Kenya
}

\author{
Robert Ouko Gwada $^{1^{*}}$ Hillary Kiplangat Bett ${ }^{1} \quad$ Kenneth Waluse Sibiko ${ }^{2}$ \\ 1. Department of Agricultural Economics and Agribusiness Management, Egerton University, P.O Box 536 \\ 20115, Nakuru, Kenya \\ 2. Department of Agricultural Economics and Rural Development, Maseno University, P.O Box, Private Bag, \\ Maseno, Kenya
}

\section{The research is financed by African Economic Research Consortium (AERC)and Egerton University}

\section{Abstract}

Dissemination, continued uptake and expansion of the area covered by push-pull technology (PPT), remain critical requirements in addressing the major constraints facing maize production such as infestation by striga weed and stem borers, and declining soil fertility for improved livelihoods. Despite increasing investment and literature on PPT in Homa Bay County, there are still smallholder farmers who for unknown reasons have chosen only to expand a smaller portion of their potential land for PPT or those who have chosen to reduce the area covered by PPT since adoption. This study econometrically addresses this information gap by looking at the rate and factors influencing extent of PPT expansion. A multi-stage sampling procedure was applied to select a sample of 240 smallholder farmers in Homa Bay County. Data were obtained through a face-to-face interviews using a pretested semi-structured questionnaire, and analyzed using censored tobit model. The results revealed relatively low PPT expansion rate of about $48.59 \%$. Tobit results revealed that gender, marital status, access to extension services, dissemination pathways, perception on the stem borer severity, napier seed availability, longevity of PPT use, total size of cultivable land, and distance to the nearest market significantly influenced the extent of PPT expansion. Interestingly, farmer-to-farmer, field days and farmer teachers were found to be the most important and effective dissemination pathways enhancing the extent of PPT expansion. Therefore, the paper recommends policies that seek to ensure equitable access to output and input markets, efficient and effective extension system, as well as those that ensure strengthening of social institutions for extensive use of PPT. Again, such policies should ensure establishment of an integrated input development system which involves all stakeholders in the development and dissemination of PPT inputs such as desmodium seeds.

Keywords: Dissemination, Continued Adoption, Extent of PPT Expansion, Censored Tobit Model

DOI: $10.7176 / \mathrm{JESD} / 10-7-08$

Publication date: April $30^{\text {th }} 2019$

\section{Introduction}

In Kenya, agriculture remains the backbone as well as the major contributor to the national economy, predominantly practiced by majority of smallholder farmers (KNBS, 2017). Despite immense, direct and indirect contribution of agricultural sector to Kenyan economy as well as to smallholder livelihoods, the sector is faced with a number of serious challenges such as declining agricultural productivity due to infestation by pest and weeds, low soil fertility conditions, adverse effects of climate change among others (Muui et al., 2013). Specifically, pests, weeds and low soil fertility have overtime constrained maize (Zea mays L.) production in Kenya, especially in the western region, and have greatly resulted in food insecurity and poverty among smallholder farmers in this region (Midega et al., 2016). Infestations by parasitic striga weed (Striga hermonthica) and lepidopteran stem borers (Busseola fusca or Chilo partellus) remain part of the major agricultural constraints experienced by almost all smallholder farmers in western part of Kenya, Homa Bay County included (Cairns et al., 2013; Khan et al., 2008a; Khan et al., 2008b; Midega et al., 2016).

Previous studies indicated that Stem borers, parasitic striga and low soil fertility jointly lead to grain yield losses of about $5-80 \%$ in Homa Bay County, and this depends on a number of biological, chemical and environmental factors (Kfir et al., 2002; Khan et al., 2008a; Khan et al., 2014). These pests and weeds competes for nutrient and moisture needs, thereby suppressing the growth of the maize plant; thus, resulting to a severe reduction in the amount of grain output or even total crop damage in severe cases.

Controlling stem borers and parasitic striga weed have been a difficult process for smallholder farmers in this region largely because of biological and nocturnal characteristics of these weeds and pests, as well as the availability of impractical and uneconomical recommended control strategies for smallholder farmers (Midega et al., 2016). In addition, Pickett et al. (2008) added that farmers in this region persistently use conventional and traditional methods such as repeated weeding, manure and fertilizer application, uprooting and crop rotation which have overtime shown minimal and localized success in controlling stem borers, parasitic striga and low soil fertility, 
thus leading to continuous reduction in yields.

To address pests and weeds constraints in order to realize its major economic objectives, Government of Kenya (Gok) identified introduction and adoption of new and improved agricultural production technologies and marketing techniques facilitated through effective dissemination pathways, as important development strategies to boost agricultural production in various agro-ecological environments (Gok, 2012). With this regard, scientists at the International Centre of Insect Physiology and Ecology (ICIPE), Kenya Agricultural and Livestock Research Organisation (KALRO), Rothamsted Research in the United Kingdom among other partners invented an integrated pest management system known as Push-pull technology (PPT) to protect smallholder maize farmers from the devastating effect of striga weed, stem borers and low soil fertility (Oswald, 2005).

Push-pull technology, therefore, involves intercropping maize with a stem borer moth repellent fodder legume called desmodium (Desmodium uncinatum), which uses stimuli-deterrent diversionary strategy to control cereal stem borers (Cook et al., 2007). Then an attractant trap plant, known as brachiaria grass or napier grass (Pennisetum purpureum) is planted along the border of the farm. The mechanism involves the push where desmodium repels stem borers and suppresses striga attack using allelopathic effect, and the pull where napier grass attracts and kills stem borers (Cook et al., 2007). Desmodium, brachiaria grass and napier grass also act as fodder for livestock production. Desmodium also act as cover crop and nitrogen fixing legume plant thus improving soil fertility and soil moisture content. Brachiaria grass or napier grass on the other hand help in maintaining soil erosion and structure through their fibrous roots. Push pull technology, therefore, helps in increasing yields, improving soil fertility and moisture content, as well as provision of fodder for livestock production (Khan et al., 2014; Chepchirchir et al., 2016; Ogot et al., 2017).

In recognition of the importance of maize on smallholder livelihoods, the Government of Kenya, ICIPE and other partners introduced push-pull technology in Homa Bay County back in 2002 with the view of ameliorating the devastating effects of striga weed, stem borer pests, and low and declining soil fertility. Again, in recognition of benefits of PPT many scholars have shown interest in assessing the rate, extent, dissemination, timing of its adoption as well as factors that influence its adoption decision.

For instance, Khan et al. (2014), Midega et al. (2016), Chepchirchir et al. (2016) and Ogot et al. (2017) identified dissemination and adoption of PPT as vehicles for increasing agricultural productivity, improving nutritional outcomes, alleviating poverty, minimizing negative environmental impacts, as well as meeting the growing demand for food. Amudavi et al. (2009), Obare et al. (2011) and Murage et al. (2012) highlighted that field days, farmers' field school, fellow farmer and farmer teacher are most efficient and effective dissemination pathways for the attainment of maximum PPT adoption. Fischler (2010) and Backson et al. (2014) also revealed that actual adoption rate and potential adoption rate of PPT in Kenya were $37 \%$ and $56.3 \%$, respectively, and this is due to extensive efforts by dissemination agents and extension staffs in transferring the technology.

Scholars emphasized that age, gender, education, farmer group, access to extension advice, distance to nearest administration center, farmers' perception on severity of stem borers and striga weed constraints, awareness of technology, access to input market among other factors play significant role in influencing PPT adoption (Khan et al., 2008a; Backson et al., 2014; Murage et al., 2015a; Murage et al., 2015b). Moreover, little literature exists on determinants of extent of PPT expansion. Amudavi et al. (2008) assessed factors influencing the expansion decision of PPT among smallholder farmers in western Kenya using logistic regression, and showed that household size, the longevity of technology use, group membership, availability of desmodium seeds and geographical location had a significant effect on PPT expansion decision.

Different stakeholders, through different dissemination pathways such as field days, farmer field school, public meetings, TV, radio, farmer teachers, farmer-to-farmer, printed materials, agricultural shows, and participatory video, have consistently disseminated PPT information for effective control of stem borers and striga weed, as well as improvement of soil fertility, especially in Homa Bay County (Amudavi et al., 2009; Obare et al., 2011; Murage et al., 2012). Despite these efforts, expansion of areas under push-pull technology has remained low, with many farmers allocating only smaller portion of their potential land for PPT, others reducing the land area allocated for PPT while others abandoning the technology for unknown reasons. However, previous studies failed to consider the factors as well as individual effect of dissemination pathways on the extent of PPT expansion. This implies that information gap exists on the determinants of extent of PPT expansion. Therefore, this study addressed this knowledge gap by econometrically analyzing the rate of PPT expansion as well as the determinants of the extent of PPT expansion.

Therefore, understanding the rate and factors determining the extent of PPT expansion through this paper helps policy-makers to develop policy measures that will ensure implementation of cost-effective and demanddriven extension or dissemination approaches for extended use of push-pull technology. In turn, this will improve smallholders' agricultural productivity, incomes as well as the general contribution of the agricultural sector to the country's economy thus subsequently help in meeting broader development goals such as sustainable development goals (SDGs) for reduced poverty and food insecurity levels. The study is also useful to the education fraternity since it provides knowledge and exposure to new research areas by contributing to the existing literature on 
dissemination, adoption and expansion of PPT by focusing on the conditions and issues for extended use of PPT. This paper is organized as follows. Section 2 provides the study area, research methodology and analytical framework. Section 3 provides study results and discussion. Finally, section 4 provides conclusion, policy implications as well as area for further research.

\section{Methodology}

\subsection{Study Area}

The study area is Homa Bay County. Administratively, Homa Bay County is situated along the shore of Lake Victoria and on the upper and lower agro-ecological zone of lower midlands in former Nyanza province in the western part of Kenya. It covers an area of 3183.3 square kilometers, and lies between latitude: $0^{\circ} 40^{\prime} 60.00^{\prime \prime} \mathrm{N}$ and longitude: $34^{\circ} 27^{\prime} 0.00^{\prime}$ ' E. It has a population of approximately 963,794 people. The area experiences semiarid climatic conditions with temperatures ranging from $26-34$ degrees Celsius. It lies at an altitude ranging from 1134 to $1230 \mathrm{~m}$ above the sea level, with bimodal rainfall pattern ranging from 250 to $1200 \mathrm{~mm}$ annually capable of supporting production of various crops and livestock. The average annual rainfall is estimated as $1000 \mathrm{~m}$ with $60 \%$ reliability level. Approximately, the long rains start from March to June of between 500mm to $1000 \mathrm{~mm}$ per annum while short rains start from September to November of amounts between $250 \mathrm{~mm}$ to $700 \mathrm{~mm}$ per annum. The choice of Homa Bay County as a study area was motivated by fact that it is one of the regions along the shore of Lake Victoria where stem borer, striga weed, climate change and low and declining soil fertility are major problems to sustainable maize production, and also one of the region where PPT has been widely disseminated. The eight sub-counties namely Suba North, Kasipul, Homa Bay Town, Karachuonyo, Suba South, KabondoKasipul and Rangwe in Homa Bay County constitute the study area.

Figure 1. Map of Homa Bay County showing the study area

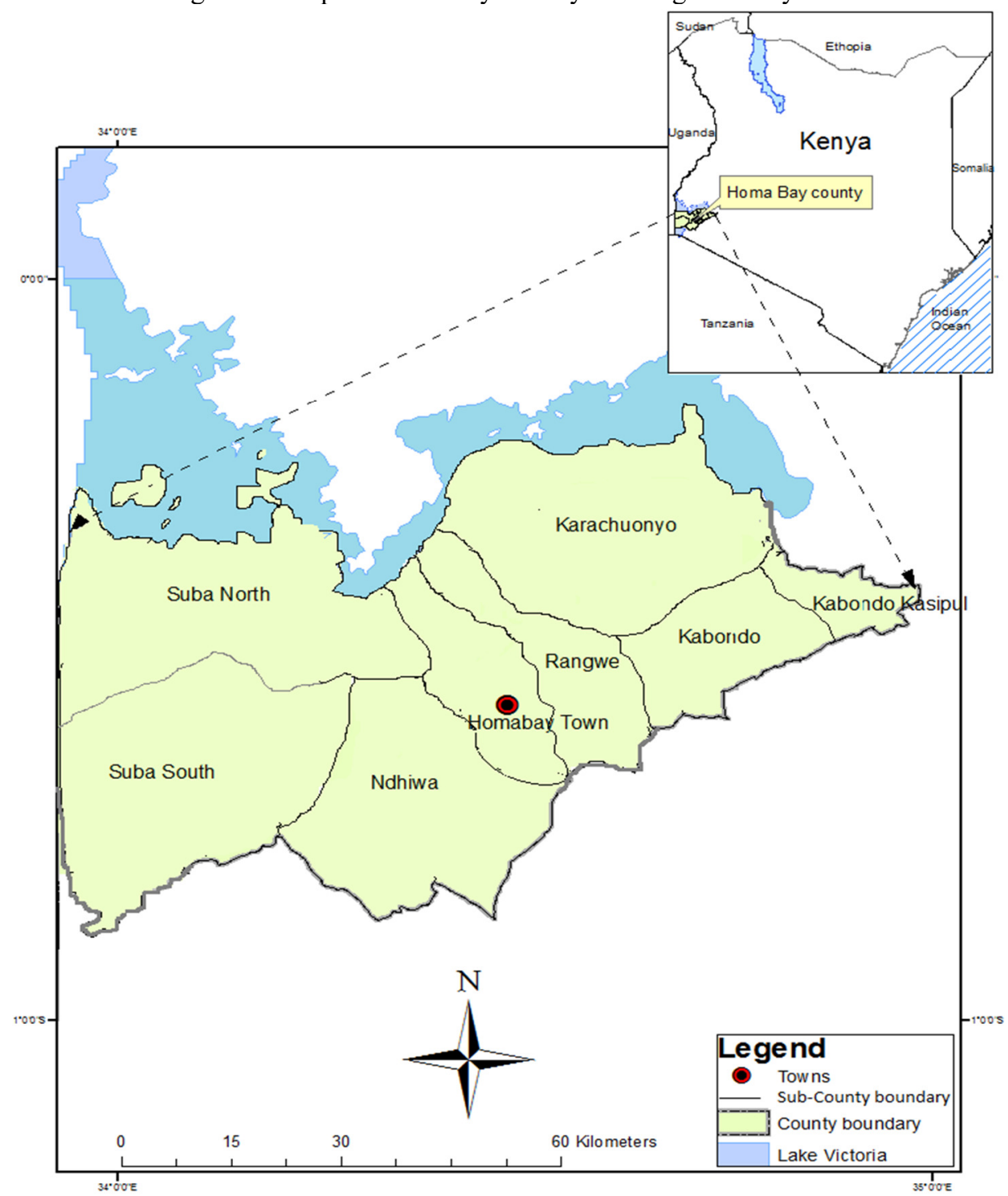




\subsection{Sampling Procedure and Sample Size}

A multistage sampling procedure was adopted to obtain data for the study. The first stage involved a purposive selection of Homa Bay County because it is one of the counties in western Kenya where stem borer and striga are most prevalent, and with declining soil fertility conditions. The second stage was the purposive selection of eight sub-counties namely Suba North, Kasipul, Homa Bay town, Karachuonyo, Suba South, Ndhiwa, Kabondo-Kasipul, and Rangwe because they represent areas where PPT has been predominantly used and widely disseminated. The third stage involved a simple random selection of six sample villages from the list of maize growing villages in each of the eight sub-counties. In total, 48 villages which were assumed to be agro climatically homogeneous were selected. The fourth and final stage involved a random selection of five maize farming households in each village resulting to a total sample of 240 maize farmers (PPT adopters, PPT dis-adopters and PPT non-adopters) for the study. However, two farmers were considered as outliers, and therefore excluded from the study.

\subsection{Data Collection}

Data collection was done between January and March of 2018. Primary data were gathered through a face-to-face interviews using a pretested semi-structured questionnaire. The questionnaires were administered with the help of a group of trained enumerators and PPT facilitators. Data collection instrument was pre-tested to assess its clarity, validity, reliability, as well as ease of use. All data that were obtained from the questionnaires were then entered and analyzed using the Statistical Package for Social Sciences (SPSS) and STATA computer software.

\subsection{Analytical Framework}

\subsubsection{Descriptive Analysis}

Descriptive statistics (Analysis of variance(ANOVA), chi-square and percentage) were used to determine the expansion rate of PPT among maize farmers, and to characterize PPT continuous users, dis-adopters and nonadopters based on different socio-economic, farm and institutional characteristics.

\subsubsection{Censored Tobit Regression Analysis}

Censored tobit regression model was used to determine the factors affecting the extent of PPT expansion measured in terms of the proportion of profitable land area under PPT expanded since adoption. This model was employed because of negative and zero values of dependent variable (extent of PPT expansion) resulting from those PPT farmers who have reduced, abandoned, or even not expanded the area under PPT since they first adopted it. Again, censored tobit model was motivated because the study did not involve a binary expansion decision but series of continuous values of land area expanded as dependent variable. Also, the model possesses the ability to correct selection bias on a randomly selected samples, resolves heteroscedasticity problem as well as meets the assumption of cumulative normal probability distribution (Newnan et al. 2003; Carroll et al. 2005; Greene, 2008).

In this context, censored tobit model was then conditioned by the farmers' socio-economic characteristics, selected dissemination pathways, farm and other institutional variables. The model is based on a random utility framework where a latent variable was used to model the factors determining the extent of PPT expansion and specified as follows;

$$
\begin{aligned}
& y_{i 1}^{*}=X_{i} \beta+v_{i} \\
& y_{i}=X_{i} \beta+v_{i}
\end{aligned}
$$

Extent of PPT expansion

$$
\mathrm{y}_{i}=\mathrm{y}^{*}{ }_{i l} \text { if } \mathrm{y}^{*}{ }_{i l} \geq 0 \text { and } \mathrm{y}_{i}=0 \text { if } \mathrm{y}^{*}{ }_{i l}<0
$$

Where, ${ }^{*}{ }_{i 1}^{*}$ represented a latent variable describing the expected utility from expanding area covered by PPT for $i^{\text {th }}$ household, censored from below at zero for values equal or less than, 0 and observed for values greater than 0 .

$y_{i}$ represented the expanded size of profitable land under PPT while $\mathrm{v}_{i}$ represent the respective error terms hypothesized to be independent and normally distributed as $u_{\mathrm{i}} \sim \mathrm{N}(0,1)$ and $u_{i} \sim \mathrm{N}\left(0, \partial^{2)}\right.$. The estimated maximum likelihood of the model took the form below (Carroll et al. 2005).

$$
L\left(\alpha, \beta, \sigma^{2}\right)=\prod_{0}\left[1-\Phi\left(w_{i}^{\prime} \alpha\right) \Phi\left(\frac{x_{i}^{\prime} \beta}{\sigma}\right)\right] \times \prod_{1}\left[\Phi\left(w_{i}^{\prime} \alpha\right) \sigma^{-1} \phi\left(\frac{y_{i}-x_{i}^{\prime} \beta}{\sigma}\right)\right]
$$

Where, $\phi$ and $\Phi$ were the density function and standard normal cumulative distribution function, respectively. Equation 2 estimates various coefficients of the explanatory variables including dissemination pathways that influence the extent of expansion of cultivable land under PPT measured as shown below.

$$
\text { ext_expan }=\left(\frac{P P T A 1-\mathrm{PPTA} 2}{\text { Lsize }}\right)
$$

Where ext expan is the extent of PPT expansion, PPT 11 is current land area covered by PPT, PPTA2 is land area covered by PPT during first time of PPT use, and Lsize is the total cultivable land owned by the farmer. 
Inclusion of dissemination pathways in the model is motivated by fact that PPT expansion decision is subject to the amount of information received among other variables. Therefore, it is important to note that PPT information reaches the farmers through different pathways, which varies in the manner the information is packaged and presented, therefore influencing the likelihood of the expansion decision differently (Mauceri et al., 2005). This information further helps in reducing uncertainty perceived by farmers, in that those who are better informed about PPT are more likely to expand the cultivable land under PPT than those with less information. However, multiplicative interactive variables were not included in the model to capture interactive effects between the pathways under analysis since almost all were not delivered in a complimentary manner thus separable in influencing absorptive information capacity.

However, only ten main dissemination pathways were included in the model with farmer-to-farmer extension used as reference category. Besides the inclusion of dissemination pathways in the model, other socio-economic, farm and institutional factors with a potential to determine the extent of PPT expansion were also included. The description and the expected signs of different variables for the study are presented in Table 1 . These explanatory variables were mainly obtained from empirical findings of the literature review as well as from the general working hypothesis.

Table 1. Description of variables and their expected Sign

\begin{tabular}{|c|c|c|c|c|}
\hline $\begin{array}{l}\text { Variable } \\
\text { Label }\end{array}$ & Description & $\begin{array}{l}\text { Variable } \\
\text { Type }\end{array}$ & Unit & $\begin{array}{l}\text { Expected } \\
\text { Sign }\end{array}$ \\
\hline ext_expan & $\begin{array}{l}\text { Extend of PPT expansion } \\
\text { (Dependent variable) }\end{array}$ & Continuous & Number & None \\
\hline Hage & Age of the household head & Continuous & Years & \pm \\
\hline Hgender & Gender of the household head & Dummy & $1=$ Male, $0=$ Female & \pm \\
\hline Mstatus & $\begin{array}{l}\text { Marital status of household } \\
\text { head }\end{array}$ & Categorical & $1=$ Married, $0=$ No spouse & \pm \\
\hline Educationlevel & Years spent in school & Continuous & Number & \pm \\
\hline L_Offincome & $\begin{array}{l}\text { Natural logarithm of total } \\
\text { income from off-farm sources }\end{array}$ & Continuous & Kes & \pm \\
\hline Hsize & Household Size & Continuous & Number of persons & \pm \\
\hline Dseed & $\begin{array}{l}\text { How a farmer perceive } \\
\text { availability of desmodium } \\
\text { seed }\end{array}$ & Categorical & $1=$ Adequate, $0=$ Otherwise & \pm \\
\hline NBseed & $\begin{array}{l}\text { How a farmer perceive } \\
\text { availability of } \\
\text { napier/bracharia seed }\end{array}$ & Categorical & $1=$ Adequate, $0=$ Otherwise & \pm \\
\hline Striperception & Perception on striga severity & Categorical & $\begin{array}{l}1=\text { Major problem, } 0=\text { not } a \\
\text { problem }\end{array}$ & \pm \\
\hline Stemperception & $\begin{array}{l}\text { Perception on stem borer } \\
\text { severity }\end{array}$ & Categorical & $\begin{array}{l}1=\text { Major problem, } 0=\text { not } a \\
\text { problem }\end{array}$ & \pm \\
\hline Gmembership & $\begin{array}{l}\text { If a farmer is member of } \\
\text { productive group }\end{array}$ & Dummy & $1=$ Yes, $0=$ No & \pm \\
\hline Acredit & Farmer has access to credit & Dummy & $1=$ Yes, $0=$ Otherwise & \pm \\
\hline Econtact & $\begin{array}{l}\text { Access to extension contact } \\
\text { in year }\end{array}$ & Dummy & $1=$ Yes, $0=$ No & \pm \\
\hline Dmarket & $\begin{array}{l}\text { Distance to the nearest } \\
\text { market }\end{array}$ & Continuous & Walking minutes & \pm \\
\hline Lsize & Total land size & Continuous & Acres & \pm \\
\hline TLunits & Total Livestock Unit & Continuous & Units & \pm \\
\hline Lallocation & $\begin{array}{l}\text { Household head's daily hours } \\
\text { for working on PPT plots }\end{array}$ & Continuous & Hours & \pm \\
\hline LTuse & Longevity of PPT use & Continuous & Years & \pm \\
\hline Pathways & $\begin{array}{l}\text { Main dissemination pathway } \\
\text { that greatly influence PPT } \\
\text { expansion decision }\end{array}$ & Categorical & $\begin{array}{l}1=\text { Fellow farmer }(\text { Reference } \\
\text { category), } 2=\text { Field days, } 3= \\
\text { Farmer teacher, } 4=\text { Farmer } \\
\text { field school, } 5=\text { Radio, } 6= \\
\text { Television, } 7= \\
\text { Print material, } 8= \\
\text { Public meeting, } 9= \\
\text { Agricultural shows, } 10= \\
\text { Participatory video }\end{array}$ & \pm \\
\hline
\end{tabular}




\section{Results and Discussion}

\subsection{Descriptive Statistics}

This study assessed the farmer socio-economic, institutional, and farm characteristics in order to explain the current conditions of the farmer. A one-way ANOVA, percentage and chi-square were conducted to establish if there were significant differences in household characteristics for various study groups namely; PPT continuous users $(n=$ $74)$, non-adopters $(n=115)$ and PPT dis-adopters $(n=49)$, and the results presented in Table 2 and 3 . The study revealed a statistically significant difference in the mean age of the household head across groups $(p=.003)$ as shown in Table 2. The mean age of household heads for the entire sample was 52 years, with slightly more elderly famers among PPT continuous users (55 years). This was followed by PPT dis-adopters with a mean age of 51 years and lastly non-adopters with 50 years. The education level was statistically significantly different across all adoption categories $(p=.000)$, with highest literacy level among continuous users (10.82 years), followed by disadopters (9.84 years), and lastly non-adopters (6.91 years). High literary level among PPT continuous users implies that smallholder farmers with higher literacy levels are much more informed, thus can effectively seek and interpret information related to the importance of different new and improved agricultural production technologies. The results in Table 2 also show that the average household size was significantly ( $p=.0111)$ largest among PPT continuous users ( 8 members), followed by dis-adopters ( 7 members), and lastly, 6 members for the non-adopters. Tropical livestock unit (TLU) was calculated with the help of Food and Agriculture Organization guidelines (2015). The mean value of tropical livestock units owned was statistically significantly different across PPT adoption categories $(p=.000)$ as shown in Table 2. Continuous users recorded highest mean value of livestock units of 7.42, followed by dis-adopters (4.34 units), and with non-adopters recording the least units (3.86 units). One-way ANOVA results also revealed that there was significant variation in mean size of cultivable land owned by sampled farmers across the study groups $(p=.000)$. Continuous users recorded the largest mean land size of 2.97 acres, followed by non-adopters with 1.82 acres, and lastly dis-adopters with an average land of 1.52 acres. Larger farm sizes among PPT continuous users indicated a positive effect of land size on continued adoption of conservational and fodder producing agricultural technologies such as PPT. Table 2 also present that there was a statistically significant difference in the average walking distances to the nearest market center across the groups $(p=.0000)$. On average, continuous users were staying closer to the market centers (13.32 walking minutes) compared nonadopters (30.28 walking minutes) and dis-adopters (20.10 walking minutes). The findings also revealed that there was a statistically significant difference in mean level of off-farm income across adoption groups $(p=.000)$. The average off-farm incomes for the whole sample was KES. 161,570.65, with continuous users registering significantly higher annual off-farm income of KES. 245,869.95 compared to dis-adopters with KES. 106,519.37 per annum and non-adopters with KES. 130,782.51 per annum

Table 2. Continuous characteristics of sample households

\begin{tabular}{|c|c|c|c|c|c|c|}
\hline \multirow[b]{3}{*}{ Variables } & \multicolumn{6}{|c|}{ PPT Adoption Status } \\
\hline & $\begin{array}{c}\text { Overall } \\
\text { sample } \\
n=238\end{array}$ & $\begin{array}{c}\text { All } \\
\text { Adopters } \\
n=123\end{array}$ & $\begin{array}{c}\text { Continuous } \\
\text { Users } \\
n=74\end{array}$ & $\begin{array}{c}\text { Dis- } \\
\text { adopters } \\
n=49 \\
\end{array}$ & $\begin{array}{c}\text { Non- } \\
\text { adopters } \\
n=115 \\
\end{array}$ & Statistics \\
\hline & $\begin{array}{l}\text { Mean/std. } \\
\text { dev. }\end{array}$ & $\begin{array}{l}\text { Mean/std. } \\
\text { dev. }\end{array}$ & $\begin{array}{l}\text { Mean/std. } \\
\text { dev. }\end{array}$ & $\begin{array}{l}\text { Mean/std. } \\
\text { dev. }\end{array}$ & $\begin{array}{l}\text { Mean/std. } \\
\text { dev. }\end{array}$ & F-test \\
\hline Age of household head & 51.79 & 53.52 & 54.86 & 51.48 & 49.93 & $5.83^{* * *}$ \\
\hline (Years) & $(9.92)$ & $(10.33)$ & (10.44) & $(9.91)$ & (9.14) & \\
\hline Education level of & 8.73 & 10.43 & 10.82 & 9.84 & 6.91 & $31.61^{* * *}$ \\
\hline household head (Years) & $(3.90)$ & (3.19) & $(3.02)$ & $(3.37)$ & $(3.78)$ & \\
\hline Household size & 7.03 & 7.63 & 7.84 & 7.33 & 6.38 & $4.59^{* *}$ \\
\hline (Number) & $(3.56)$ & $(3.47)$ & $(3.45)$ & $(3.51)$ & $(3.13)$ & \\
\hline Daily labor allocation & 25.90 & 26.00 & 27.24 & 24.12 & 25.80 & 1.18 \\
\hline (Hours) & (11.09) & $(10.93)$ & $(11.14)$ & $(10.44)$ & $(11.31)$ & \\
\hline Land size (Acres) & 2.12 & 2.39 & 2.97 & 1.52 & 1.82 & $27.31^{* * *}$ \\
\hline & $(1.35)$ & $(1.37)$ & $(1.34)$ & $(0.89)$ & $(1.26)$ & \\
\hline Distance to the nearest & 22.91 & 16.02 & 13.32 & 20.10 & 30.28 & $16.66^{* * *}$ \\
\hline $\begin{array}{l}\text { market center (Walking } \\
\text { minutes) }\end{array}$ & $(21.36)$ & $(9.27)$ & $(7.69)$ & $(10.01)$ & $(27.40)$ & \\
\hline Tropical livestock units ${ }^{\mathrm{a}}$ & $\begin{array}{l}5.06 \\
(5.10)\end{array}$ & $\begin{array}{c}6.19 \\
(5.87)\end{array}$ & $\begin{array}{c}7.42 \\
(6.07)\end{array}$ & $\begin{array}{c}4.34 \\
(5.06)\end{array}$ & $\begin{array}{c}3.86 \\
(3.80)\end{array}$ & $12.76^{* * *}$ \\
\hline Off farm income (KES) & $\begin{array}{c}161570.65 \\
(160527.16)\end{array}$ & $\begin{array}{l}190356.30 \\
(188233.9)\end{array}$ & $\begin{array}{c}245869.95 \\
(221981.46)\end{array}$ & $\begin{array}{l}106519.37 \\
(56480.23)\end{array}$ & $\begin{array}{c}130782.51 \\
(117488.76)\end{array}$ & $17.29^{* * *}$ \\
\hline
\end{tabular}

Note: Mean variables shown with standard deviations in parenthesis; $* * *, * *$ and $*$ denote significance at $1 \%, 5 \%$ and $10 \%$ levels, respectively. ${ }^{a}$ TLU for Africa South of Sahara is typically taken to be equivalent to: Cattle $=0.50$, sheep $=0.10$, Goat $=0.10$, Pigs $=0.25$, Asses $=0.50$, Horses $=0.50$, Mules $=0.60$, Camels $=0.70$, or Chicken $=0.01$ 
(FAO, 2015).

Table 3 shows the results of categorical variables for various study groups, and the resulting chi-square statistics. Overall, the results show that female-headed households were significantly $(p=.000)$ fewer than maleheaded households for each PPT adoption category. Specifically, the proportion of male-headed household for PPT continuous users was $82.43 \%$, followed by dis-adopters (63.27\%) and lastly non-adopters (53.91\%). Overall, higher percentage of the continuous users $(83.78 \%)$, non-adopters $(54.78 \%)$ and dis-adopters $(69.39 \%)$ were found to members of at least one productive farmer organization. However, these results were statistically significant ( $p$ $=.000$ ) across the groups as shown in Table 3 . This indicates that PPT continuous users had significantly higher group membership compared to dis-adopters and non-adopters. Although, more than half of sampled smallholder farmers in each adoption category had access to credit services, it was revealed that there were statistically significant differences $(p=.000)$ in levels of credit access across these categories. Continuous users therefore registered highest level of credit access $(83.78 \%)$, followed by dis-adopters $(69.39 \%)$ and lastly by non-adopters $(67.23 \%)$. Higher level of credit access across these PPT adoption groups is as a result of consistent harmonization in the delivery system and design of formal financial services in rural areas as well as emergence of many informal banking or lending institutions such as self-help groups, merry go rounds among others.

The result on farmers' perception on the striga weed severity showed that there was a significant difference $(p=.000)$ on how farmers in these adoption categories perceive striga severity as shown in Table 3 . The majority (70.27\%) of PPT continuous users perceived striga infestation as a major constraint. Similarly, $44.90 \%$ of disadopters perceived striga infestation as a major constraint. Contrary, the result indicated that over $50 \%$ of nonadopters perceived striga infestation as not a problem, whereas only $24.35 \%$ and $16.52 \%$ perceived it as a minor problem and a major problem, respectively. The results on perception on stem borer severity were significantly different $(p=.000)$ across each category of farmers. The stem borer infestation was viewed as a major problem by over $70 \%$ of continuous users, with only $16.22 \%$ and $10.81 \%$ mentioning it as a minor and not a problem, respectively. Again, $46.94 \%$ of dis-adopters perceived the stem borer infestation as a minor problem, with about $30.61 \%$ and $22.45 \%$ rating it as a major problem and not a problem, respectively. Furthermore, the percentages derived from the results indicated that $54.78 \%$ of non-adopters did not perceive stem borer infestation as a problem, with only $28.70 \%$ and $16.52 \%$ viewing it as a minor problem and as a major problem, respectively.

Further results showed that there was significant difference $(p=.000)$ in the level of access to extension contact across each category; where continuous users registered greatest proportion of access to extension contacts $(97.30 \%)$, followed by dis-adopters $(61.22 \%)$ and lastly non-adopters $(52.17 \%)$. Nearly half of PPT non-adopters (47.83\%) never have contact with extension agents, compared to only $38.78 \%$ and $2.70 \%$ who did not have any contact among dis-adopters and continuous users, respectively. Chi-square results also show that, there were significant differences $(p=.000)$ in the way farmers in each PPT adoption category viewed the availability of desmodium seeds. The results showed that greatest percentage of non-adopters $(93.91 \%)$ stated that desmodium seed is inadequate, followed by dis-adopters (93.88\%) and lastly by continuous users $(51.35 \%)$. This is a clear indication that lack of desmodium seed is a major setback to continued use and expansion of PPT. Chi-square result further revealed that there were significant differences $(p=.000)$ in the way farmers viewed napier or brachiaria grass seed availability. The study found that $72.97 \%$ of continuous users mentioned that napier or brachiaria grass seed availability is adequate. However, contrary results were found for dis-adopters and nonadopters, where the majority, $81.63 \%$ and $75.65 \%$, respectively, mentioned that napier or brachiaria grass seeds were inadequate. 
Table 3. Categorical characteristics of sample households

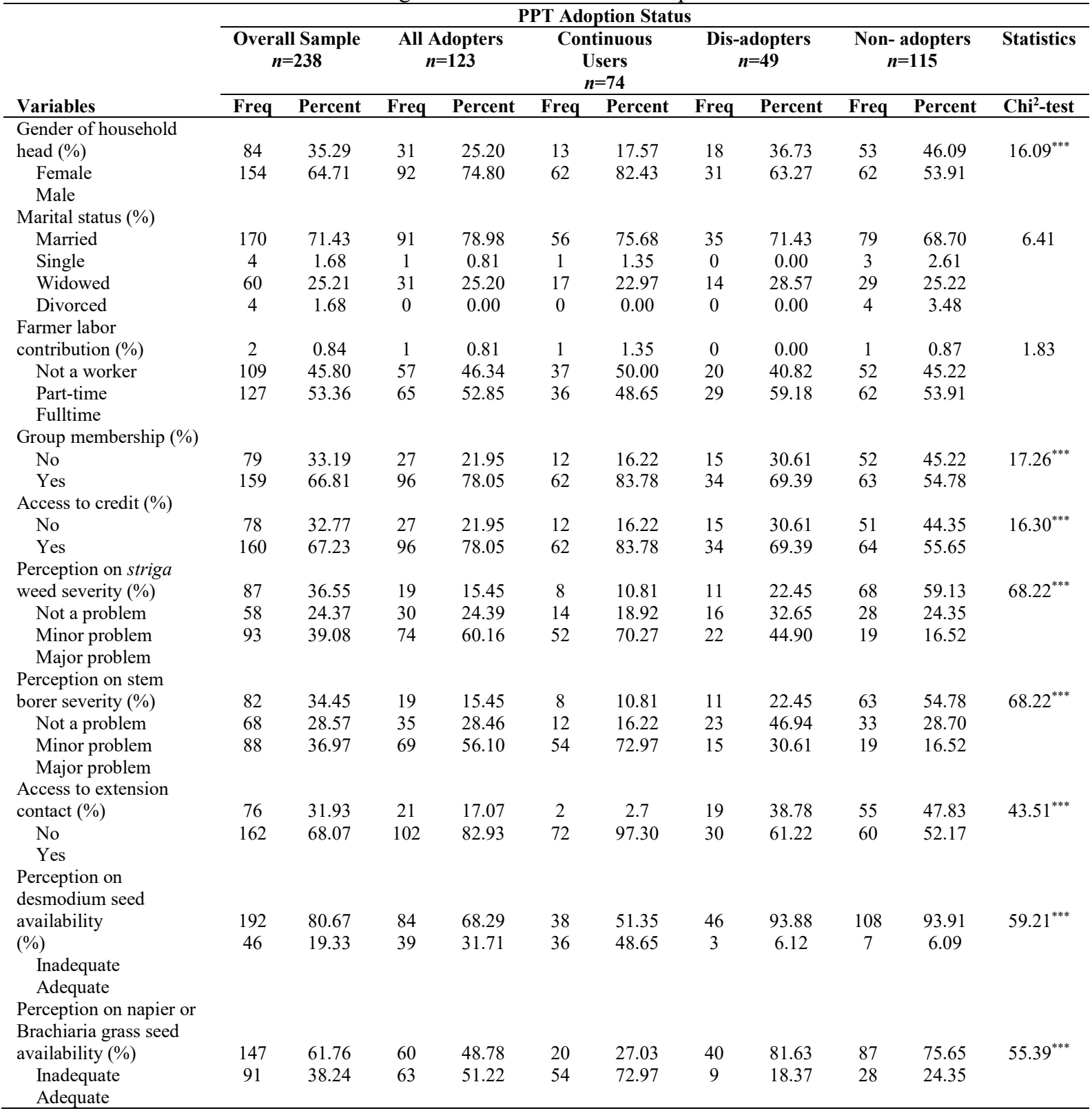

Note: $* * *, * *$ and $*$ denote significance at $1 \%, 5 \%$ and $10 \%$ levels, respectively.

\subsection{Rate of Push-Pull Technology Expansion and Determinants of Extent of Expansion}

The study sought to investigate whether farmers who adopted PPT have expanded the area under since adoption. Results in Figure 2 shows that over 50\% of adopters did not expand the area under PPT since they first adopted it. The majority have reduced the amount of land allocated to PPT, with some abandoning the technology. Only $48.59 \%$ of adopters have actually increased the area allocated to PPT since first they adopted it. This finding is consistent with that of Amudavi et al. (2008) who found that the average expansion rate of PPT in western Kenya is less than $50 \%$. They reported that only $16 \%$ of the sampled farmer had expanded PPT use.

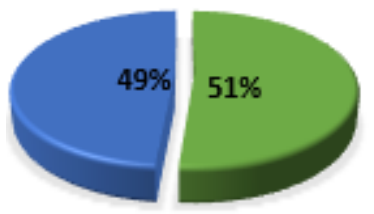

Figure 2. Rate of push-pull technology expansion 
To analyze the effects of farmer socioeconomic characteristics, farm characteristics, institutional characteristics as well as dissemination pathways on the extent of PPT expansion, a censored tobit model was used, and the results presented in Table 4. A censored tobit model was preferred due to presence of many negative and zero values for farmers who reduced farm area allocated to practice PPT or those who drop PPT, and those who did not expand the area under PPT since they first adopted, respectively. The extent of PPT adoption was investigated since it is an important innovative strategy that can help in the intensification of maize and livestock production in Kenya. The censored tobit model was estimated using maximum log likelihood estimation method, and the results presented in Table 4. However, it is important to note that only farmers who were currently using PPT or previously practiced and dropped it afterward were considered for the analysis. The log likelihood ratio of 26.478 indicates how the model quickly converges. The likelihood ratio chi-square statistic $\left(\operatorname{LR~} \operatorname{chi}^{2}(25)=142.31\right.$, $p=0.000$ ) and Pseudo $\mathrm{R}^{2}$ of 1.592 shows that the model wholly and significantly fits the data well, in that the variation in extent of PPT expansion was explained by the regressors considered in the tobit model. The observations that were left censored at zero were 62 while uncensored observations were 61 . The dependent variable was obtained as the ratio between the difference in the land sizes allocated to PPT during the first time of use and current PPT area to the total farm size.

Table 4. A censored tobit regression results for factors influencing the extent of PPT expansion

\begin{tabular}{lcc}
\hline Variable & Coefficient & Standard Error \\
\hline Age of household head & 0.003 & 0.003 \\
Gender & $0.146^{* * *}$ & 0.053 \\
Marital status & $0.044^{*}$ & 0.023 \\
Education level & 0.004 & 0.006 \\
Household size & 0.001 & 0.006 \\
Farming experience & -0.006 & 0.003 \\
Total size of cultivable land & $-0.034^{* *}$ & 0.017 \\
Tropical livestock unit & 0.003 & 0.004 \\
Membership in farmer group & -0.009 & 0.039 \\
Extension contact & $0.156^{* *}$ & 0.074 \\
Distance to the nearest market center & $-0.004^{*}$ & 0.002 \\
Perception on the severity of stem borer & $0.079^{* * *}$ & 0.026 \\
Perception on the severity of striga weed & -0.013 & 0.028 \\
Perception on the availability of desmodium seeds & -0.013 & 0.043 \\
Perception on the availability of napier or brachiaria seeds & $0.147^{* * *}$ & 0.043 \\
Longevity of PPT use & $0.031^{* * *}$ & 0.006 \\
Pathways & & \\
Field days & & 0.046 \\
Farmer teachers & -0.016 & 0.054 \\
Farmer school & -0.042 & 0.059 \\
Radio & $-0.132^{* *}$ & 0.068 \\
Television program & $-0.115^{*}$ & 0.077 \\
Print material & $-0.305^{* * *}$ & 0.081 \\
Public meeting & $-0.222^{* * *}$ & 0.071 \\
Agricultural show & $-0.233^{* * *}$ & 0.091 \\
Participatory video & $-0.304^{* * *}$ & 0.094 \\
Constant & $-0.204^{* *}$ & 0.190 \\
/sigma & $-0.498^{* *}$ & 0.011 \\
\hline
\end{tabular}

Note: Farmer to farmer extension used as reference category; $\log$ likelihood $=26.478 ; \log \operatorname{likelihood} \chi^{2}(25)=$ 142.31, Prob $>\chi^{2}=0.000$; Pseudo $\mathrm{R}^{2}=1.593$; Number of observation $=123 ; * * * * *$ and $*$ denote significant at $1 \%, 5 \%$ and $10 \%$ probability levels, respectively.

According to the results in Table 4, gender had a positive and significant influence on the extent of PPT expansion at $1 \%$ significance level. By implication, households headed by male persons were more likely to increase the area allocated to PPT compared to female-headed ones. The results showed that the extent of PPT expansion for households headed by male was significantly greater than those headed by female by 0.146 acres, ceteris paribus. A possible explanation for this observation is that male farmers have higher access to necessary resources and agricultural information that increases their chances of expanding the use of new agricultural technologies than female farmers. This is consistent with the findings by Backson et al. (2014) and Theriault et al. (2017) who argued that more male-headed households are probably intensifying technological use because of highincome levels compared to adopting female-headed households.

As expected, marital status of the household head had a significant positive influence on the extent of PPT expansion. This implies that the extent of PPT expansion for household heads without spouses was significantly 
lower than that of married farmers by 0.044 acres, at the $10 \%$ significance level when other factors are held constant. This can be attributed to the joint decision-making among married couples that helps them better appreciate the benefits of PPT compared to single, widowed and divorced families. The argument is that in married families, men are expected to engage women in decision-making on new technology attributes. Since women have limited access to opportunities and productive agricultural resources for commercial inputs than men as argued by Murage et al. (2015) and Tamru et al. (2017), engaging them in farm decision-making process grant them such access that enables them to intensify the use of new agricultural technology for higher agricultural growth especially in developing countries. Married families could also be associated with higher own farm labor for extensive use of technology, where the spouses work together as opposed to widowed, single and divorced families that my lack resources and family labor for extensive use of PPT.

Total size of cultivable land had a negative significant influence on the extent of PPT expansion at 5\% level of significance. However, this is against prior expectation. It implies that a unit increase in total size of cultivable land owned by a farmer reduces the extent of PPT expansion by 0.034 acres when other factors are held constant. In other words, farmers with smaller land sizes were more likely to expand area under PPT compared to those with large pieces of land. This may be attributed to the fact that those farmers with small lands have got the incentive to improve the productivity of their small plots by intensifying the usage of integrated technologies compared to those with large farm sizes. Again, farmers with smaller land sizes are more willing to invest and expand the use of technologies that provides both food crop and fodder crop at the same time such as PPT compared to those with larger farms (Pender and Gebremedhin, 2007). However, this finding was inconsistent with those from a study by Wimberly et al. (2017) who reported that households with larger farms were more likely to expand their cropland acreage than those with smaller farms.

Access to extension contact or service positively and significantly influenced the extent of PPT expansion at $5 \%$ level of significance. The positive influence of extension contacts implies that the more the PPT farmer has contacts with extension and development agents, the more they tend to increase the area allocated to PPT by 0.156 acres, ceteris paribus. This also implies that intensive discussions between farmers and agricultural extension officers help improve acceptance and extended use of integrated crop and livestock production technologies such as PPT. The agents deliver extension information, skills, knowledge, and resources that enable farmers to learn about different components of the technology, thus ensuring extended use. These results are consistent with results of earlier studies (Amudavi et al., 2008; Regmi et al., 2017; Mutemim and Sakwa, 2017).

Distance to the nearest market center had a negative significant influence on the extent of PPT expansion at $10 \%$ level of significance. This implies that as distance to the nearest market increase by one unit, the likelihood of PPT expansion reduces by 0.004 acres, when other factors are held constant. These results imply that households living nearer the market centers have better access to information and markets for both inputs and outputs; thus, they are more likely to expand the use of new technologies being promoted including PPT. This inverse relationship implies that, as the distance to the nearest market center increases, there is a high likelihood of an increase in transformation and transaction costs, thereby lowering the probability of PPT expansion (Backson et al., 2014; Iiyama et al., 2017).

Farmers perception on severity of stem borer infestation has a positive and significant influence on the extent of PPT at 1\% significance level. The reason is that the central role of PPT is to fight stem borer, striga weed and poor soil fertility which are major production constraints in the study area. As such, farmers' perceptions on severity of stem borer influenced the decision on how much land area to be added for practicing PPT. According to the results, PPT farmers who perceive the stem borer as a major constraint broadly expanded the PPT use by 0.079 acres compared to those who perceived it as a minor problem. Similarly, farmer perception on the availability of napier or brachiaria seeds had a positive significant influence on the extent of PPT at $1 \%$ significance level. This suggests that PPT farmers who perceived that napier or brachiaria seed were adequately available were more likely to expand the PPT area use by 0.147 acres compared to their counterparts who perceived it as inadequate.

As expected, the influence of longevity of PPT use on the extent of PPT expansion was positive and significant at $1 \%$ significance level as shown in Table 4. An increase in the experience a farmer has on PPT, the higher the likelihood to increase the area allocated to PPT by about 0.031 acres ceteris paribus. This result is consisted with that by Amudavi et al. (2008) who found a significant positive association between longevity of PPT use on the farm and PPT expansion decision. They argued that one-unit increase in the number of years a farmer has been enjoying the benefits of PPT increased the likelihood of PPT expansion by 0.43 .

In order to evaluate the effect of dissemination pathways on the extent of PPT expansion, PPT adopters were presented with a list of 10 dissemination pathways that have been commonly and widely used to catalyze PPT diffusion and asked to indicate the central pathway or information source they perceived to have influenced their PPT expansion decision greatly. Farmer-to-farmer extension being the commonly mentioned pathway, it was used as base or reference category in the censored tobit regression, and results are presented in Table 4 . The result generally shows that dissemination pathways positively influence the extent of PPT expansion due to the participatory and demand-driven approach followed by the extension agents. The null hypothesis of the study was 
that the effect of the farmer-to-farmer extension on the extent of PPT expansion is the same as those of other pathways.

From the results in Table 4, it can be concluded that when other factors are held constant, the effect of the farmer-to-farmer extension on the extent of PPT expansion is significantly higher than that of farmer school by 0.132 acres at $5 \%$ significance level. The effect of the farmer-to-farmer extension on the extent of PPT expansion is also significantly higher than that of Radio by 0.115 acres at $10 \%$ significance level, when other factors are held constant. The effect of a television program on the extent of PPT expansion is significantly lower by 0.305 acres than that of farmer-to-farmer extension, at $1 \%$ significance level. The influence of print media on the extent of PPT expansion is significantly lower by 0.222 acres than that of farmer-to-farmer extension, at $1 \%$ significance level. Similarly, when other factors are held constant, the influence of public meeting on the level of PPT expansion is 0.233 acres lower than that of farmer-to-farmer extension at $1 \%$ level. The marginal effect of the farmer-tofarmer extension on the extent of PPT expansion is significantly higher by 0.304 acres than that of the Agricultural show, at $1 \%$ level of significance when other factors are held constant. Finally, the marginal influence of participatory video on the extent of PPT expansion is significantly lower by 0.204 acres than that of farmer-tofarmer extension at 5\% significance level, ceteris paribus.

Looking at these findings, it can be said that one of the most effective pathways, is farmer-to-farmer because it ensures clear demonstration of the PPT efficacy as well as ensuring mutual support that significantly increases the probability as well as the extent of PPT expansion compared to other pathways. In a related study, Martini et al. (2017) also revealed that farmers perform an essential role as reliable agricultural information disseminators which are related to agroforestry technologies especially in areas where language barriers and limited access to government extension providers act as major constraints to such dissemination efforts.

Even though there were no significant differences in the effect of farmer-to-farmer extension and field days and farmer teachers on the extent of PPT expansion, an F-test was conducted to estimate further whether their coefficients were the same. The F-statistic results in Table 5 showed that the coefficients of farmer-to-farmer extension and field day were not significantly different $(p=0.9618)$ from each other.

Table 5. A joint test of significance result for farmer-farmer extension (0) and field days (1)

(1) $[$ model] 0b. Pathways - [model]1. Pathways $=0$

$\mathrm{F}(1,100)=0.00$

Prob $>\mathrm{F}=0.9618$

Again, the F-statistic results on Table 6 shows that the coefficient of farmer-to-farmer extension and farmer teachers are not significantly different $(p=0.7189)$ from each other. These results imply that the effect of farmerto-farmer extension, field day, and farmer teachers on the extent of PPT expansion is almost the same.

Table 6. A joint test of significance result for farmer-farmer extension (0) and farmer teachers (2)

(1) $[$ model] 0b. Pathways - [model]2. Pathways $=0$

$\mathrm{F}(1,100)=0.13$

Prob $>F=0.7189$

Farmer-to-farmer pathway being one of the most important and effective dissemination pathways, it can be said that field days and farmer teachers are also most effective and efficient pathways influencing expansion decision as well as the extent of PPT expansion significantly compared to other approaches. These findings are consistent with those from other studies that established that field days, farmer teachers, fellow farmer, and field school were the most preferred and effective pathways that significantly increase the likelihood of adopting PPT (Amudavi et al., 2008; Amudavi et al., 2009; Murage et al., 2011; Murage et al., 2012). Generally, a combination of dissemination pathways in the diffusion of PPT information is recommended as this will increase the likelihood of adopting, expanding and sustaining the use of such knowledge, capital and labor intensive technology.

\section{Conclusions and policy recommendation}

The study revealed significant variations in farmer socio-economic, institutional, and farm characteristics, across PPT adoption categories. The study also revealed a relatively low PPT expansion rate of $48.59 \%$. It was established that important factors determining PPT uptake decision also determine its extensive use. The study revealed that gender of household head, marital status, access to extension services, dissemination pathways, perception on the stem borer severity, napier seed availability, longevity of PPT use positively and significantly influenced the extent of PPT expansion. However, total size of cultivable land, and distance to the nearest market center had a negative significant influence on the extent of PPT expansion. Interestingly, farmer-to-farmer, field days and farmer teachers were found to be the most important and effective dissemination pathways enhancing the extent of PPT expansion.

From the results, the study recommends policy measures that seek to ensure equitable access to quality formal education, adequate desmodium seeds and other agricultural inputs, as well as output and input markets. These policies should also ensure the establishment of integrated input development system which involves all stakeholders in the development and distribution of all PPT inputs including desmodium seeds. Such policies 
should also ensure efficient extension delivery system which involves incorporation of "model farmers" as a key pathway in technology dissemination. There is also the need to strengthen societal ties through the formation of local institutions as well as strengthening of existing ones as this will ensure perception and attitude change and bargaining power while offering platforms for knowledge and information transfers for agricultural development. The study recommends further research on substitutability and complementarity of agricultural technologies in PPT expansion decisions, using robust and dynamic panel data models to control the selection bias and unobserved heterogeneity in assessing decisions on PPT expansion.

\section{Conflict of interests}

The authors have not declared any conflict of interests.

\section{Acknowledgement}

The authors would like to acknowledge the contributions made by the Egerton University and African Economic Research Consortium (AERC) for funding this work. We are also grateful to other staffs, farmers, facilitators, enumerators, and all others for their assistance.

\section{References}

Amudavi, D., Khan, Z., Midega, C., Pickett, J., Lynam, J. \& Pittchar, J. (2008), "Push-Pull technology and determinants influencing expansion among smallholder producers in western Kenya". In Proceedings of the 24th Annual Conference, Association for International Agricultural and Extension Education, Costa Rica, 38-50.

Amudavi, D., Khan, Z., Wanyama, J., Midega, C., Pittchar, J., Nyangau, M., Hassanali, A. \& Pickett, J. (2009), "Assessment of technical efficiency of farmer teachers in the uptake and dissemination of push- pull technology in western Kenya", Crop Protection 28(11), 987-996.

Backson, M., Obare, G. \& Murage, A. (2014), "Estimating the adoption rates of two contrasting striga weeds control technologies in Kenya", Quarterly Journal of International Agriculture 53(3) 225-242.

Cairns, J., Hellin J., Sonder. K., Araus, J., MacRobert, J., Thierfelder, C. \& Prasanna, B. (2013), “Adapting maize production to climate change in Sub-Saharan Africa", Food Security 5(3), 345-360.

Carroll, J., McCarthy, S. \& Newman, C. (2005), "An econometric analysis of charitable donations in the Republic of Ireland”, Economic and Social Review 36(3), 229-249.

Chepchirchir, R., Macharia, I., Murage, A., Midega, C. \& Khan, Z. (2016), "Impact assessment of push-pull technology on incomes, productivity and poverty among smallholder households in eastern Uganda," In proceeding of the 5th international conference of the African association of agricultural economists, held in Addis Ababa, Ethiopia, September, 2016, 23-26.

Cook, S., Khan, Z. \& Pickett, J. (2007), "The use of push-pull strategies in integrated pest management", Annual Review of Entomology 52, 375-400.

Fischler, M. (2010), "Impact Assessment of Push-Pull Technology in Eastern Africa”, Nairobi, Kenya: ICIPE Science Press.

Food and Agriculture Organization (FAO) (2015), "Production yearbook 2014. No. 85, " Rome, Italy.

Government of Kenya (2012), "Kenya Vision 2030. A Globally Competitive and Prosperous Kenya”, Nairobi, Kenya: Government Printers.

Greene, W. (2008), “Econometric Analysis, 6th edition”, USA: Prentice-Hall International Inc.

Iiyama, M., Derero, A., Kelemu, K., Muthuri, C. Kinuthia, R., \& Ayenkulu, E. (2017), “Understanding patterns of tree adoption on farms in semi-arid and sub-humid Ethiopia"" Agroforestry Systems 91(2), 271-293.

Kenya National Bureau of Statistics (2017), "Third Quarter 2017 Gross Domestic Product Report”, Nairobi, Kenya: Government of Kenya printing press.

Kfir, R., Overholt, W., Khan, Z. \& Polaszek, A. (2002), "Biology and management of economically important lepidopteran cereal stem borers in Africa”, Annual Review of Entomology 47, 701-731.

Khan, Z., Amudavi, M., Midega, C., Wanyama, J. \& Pickett, J. (2008a), "Farmers' perception of a push-pull technology for control of cereal stem borers and striga weed in western Kenya", Crop protection 27(6), 976987.

Khan, Z., Midega, C., Pittchar, J., Murage, A., Birkett, A., Bruce, A. \& Pickett, J. (2014), “Achieving food security for one million sub-Saharan African poor through push-pull innovation by 2020," Philosophical Transactions of the Royal Society B: Biological Sciences 369(639), 20120284, available at: http://doi.org/10.1098/rstb.2012.0284 (accessed 16 September 2017).

Khan, Z., Pickett, J., Hassanali, A., Hooper, A. \& Midega, C. (2008b), "Desmodium species and associated biochemical traits for controlling striga species: Present and future prospects", Weed Research 48(4), 302306.

Martini, E., Roshetko, J. \& Paramita, E. (2017), “Can farmer-to-farmer communication boost the dissemination of 
agroforestry innovations? A case study from Sulawesi, Indonesia”, Agroforestry Systems 91(5), 811-824.

Mauceri, M., Alwang, J., Norton, G. \& Barrera, V. (2005), “Adoption of integrated pest management technologies: A case study of potato farmers in Carchi, Ecuador", A paper presented at American Agricultural Economics Association Annual Meeting, held in Providence, Rhode Island, July 24-27.

Midega, C., Pickett, J., Antony, H., Pittchar, J. \& Khan, Z. (2016), "Maize landraces are less affected by Striga hermonthica relative to hybrids in western Kenya", Weed Technology 30(1), 21-28.

Murage, A., Amudavi, D., Obare, G., Chianu, J. \& Khan, Z. (2011), "Determining smallholder farmers' preferences for push-pull technology dissemination pathways in western Kenya" International Journal of Pest Management 57(2), 133-145.

Murage, A., Midega, C., Pittchar, J., Pickett, J. \& Khan, Z. (2015a), "Determinants of adoption of climate-smart push-pull technology for enhanced food security through integrated pest management in eastern Africa", Food Security 7(3), 709-724.

Murage, A., Obare, G., Chianu, J., Amudavi, D., Midega, C., Pickett, J. \& Khan, Z. (2012), "The effectiveness of dissemination pathways on adoption of push-pull technology in western Kenya", Quarterly Journal of International Agriculture 51(1), 51-71.

Murage, A., Pittchar, J., Midega, C., Onyango, C. \& Khan, Z. (2015b), “Gender specific perceptions and adoption of the climate-smart push-pull technology in eastern Africa", Crop Protection 76, 83-91.

Mutemim, M. \& Sakwa, M. (2017), "Challenges influencing participation of smallholder farmers in legume agribusiness in Ibeno location, Kisii County, Kenya," International Journal of Social Sciences and Information Technology 3(1), 1541 - 1558.

Muui, C., Muasya, R. \& Kirubi, D. (2013), "Baseline survey on factors affecting sorghum production and use in eastern Kenya", African Journal of Food, Agriculture Nutrition and Development 13, 7339-7342.

Newman, C., Henchion, M. \& Matthews, A. (2003), "A double-hurdle model of Irish household expenditure on prepared meals", Applied Economics 35(9), 1053-1061.

Obare, G., Murage, A., Chianu, J., Amudavi, D., Pickett, J. \& Khan, Z. (2011), "Duration analysis of technology adoption effects of dissemination pathways: A case of push-pull technology for control of striga weeds and stem borers in western Kenya", Crop Protection 30(5), 531-538.

Ogot, N., Pittchar, J., Midega, C. \& Khan, Z. (2017), "Impact of push-pull technology on the nutritional status of farmers' children in western Kenya”, African Journal of Food, Agriculture, Nutrition and Development 17(4), 12953-12974.

Oswald, A. (2005), "Striga control technologies and their dissemination", Crop Protection 24(4), 333-342.

Pender, J. \& Gebremedhin, B. (2007), "Determinants of agricultural and land management practices and impacts on crop production and household income in the highlands of Tigray, Ethiopia", Journal of African Economies 17(3), 395-450.

Pickett, J., Khan, Z., Hassanali, A., Hooper, A. \& Midega, C. (2008), "Desmodium species and associated biochemical traits for controlling striga species: Present and future prospects", Weed Research 48, 302-306.

Regmi, N., Dhakal, N. \& Ghimire, B. (2017), "Determinants of farmers' adaptation to climate change: A case from Syangja district of Nepal", Journal of Agricultural Economics, Extension and Rural Development 5(7), $658-663$.

Tamru, S., Minten, B., Alemu, D. \& Bachewe, F. (2017), “The rapid expansion of Herbicide use in smallholder agriculture in Ethiopia: Patterns, drivers, and implications", The European Journal of Development Research 29(3), 628-647.

Theriault, V., Smale, M. \& Haider, H. (2017), "How does gender affect sustainable intensification of cereal production in the West African Sahel? Evidence from Burkina Faso", World Development 92, 177-191.

Wimberly, M., Janssen, L., Hennessy, D., Luri, M., Chowdhury, N. \& Feng, H. (2017), "Cropland expansion and grassland loss in the eastern Dakotas: New insights from a farm-level survey”, Land Use Policy 63, 160-173. 